\title{
New Forms of Political Participation: Searching for Expert Citizens and Everyday Makers
}

\author{
YAOJUN LI AND DAVID MARSH*
}

\begin{abstract}
Declining political participation has caused much concern among political scientists and politicians. This article builds upon Henrik Bang's conceptualization of Expert Citizens and Everyday Makers as new forms of political participation. Using the 2001 Home Office Citizenship Survey, we identify four types of political participant: Political Activists, Expert Citizens, Everyday Makers and Non-Participants. We assess the socio-demographic and cultural factors underlying these different types of participant. We then move on to explore the association between the types of political participation and two domains of political beliefs/actions: political trust and efficacy; and political contacting and voice. Our analysis shows significant differences between the types of participant in the two domains under investigation and thus lends support to our development of Bang's conceptualization of new forms of political participation as useful tools in empirical research.
\end{abstract}

The issue of political participation has received a great deal of attention in recent years from academics, journalists and politicians across most liberal democracies. To a large extent, this reflects concerns about the decline in voting, party membership and other mainstream political activity. ${ }^{1}$ In this context, it is perhaps unsurprising that there is a growing body of work on political participation. ${ }^{2}$

In Britain, Pattie, Seyd and Whiteley have provided the most recent quantitative study of participation and we discuss it at points throughout this article. ${ }^{3}$ However, as Marsh, O'Toole and Jones argue, they operate with a narrow conceptualization of 'the political' and political participation. ${ }^{4}$ In addition, it is interesting that Pattie, Seyd and Whiteley pay

* Institute for Social Change, Manchester University; and Department of Sociology, Birmingham University, respectively.

${ }^{1}$ In Britain, for example, the turnout in the 2001 general election was 59 per cent, 12 percentage points lower than in 1997 and 25 points lower than the post-war high of 84 per cent in 1950. It did rise in the 2005 election, but only to 61 per cent. In relation to young people, the picture was even more disturbing: MORI's figures suggest that the turnout rate for 18-24 year-olds dropped from 39 per cent in 2001 to 37 per cent in 2005, see $<$ www.mori.com/polls/2005/election-aggregate.shtml $>$. In a similar vein, the combined membership of British political parties is little more than a half that of the largest British interest group, the Royal Society for the Protection of Birds, see D. Marsh T. O'Toole and S. Jones, Young People and Politics in the UK (Basingstoke: Palgrave, 2006), p. 2.

${ }^{2}$ See, for example, M. Henn, M. Weinstein and D. Wring, 'A Generation Apart? Youth and Political Participation in Britain', British Journal of Politics and International Relations, 4 (2002), 167-92.

${ }^{3}$ C. Pattie, P. Seyd and P. Whiteley, Citizenship in Britain: Values, Participation and Democracy (Cambridge: Cambridge University Press, 2004); and P. Norris, The Demographic Phoenix (Cambridge: Cambridge University Press, 2002).

${ }^{4}$ Marsh, O'Toole and Jones, Young People and Politics in the UK, develop four criticisms of the existing literature on political participation and only partially exempt Pattie, Seyd and Whiteley from the first and fourth of these. They contend that the literature (i) operates with a narrow definition of politics; (ii) imposes this narrow definition of politics on respondents; (iii) sees apathy as participation's main, if not only, 'other', when many citizens are not apathetic, but rather alienated from formal politics; and (iv) imposes a particular, largely top-down, view of citizenship and democracy on respondents which many do not accept. See also T. O'Toole, D. Marsh and S. Jones, 'Political Literacy Cuts Both Ways: The Politics of Non-Participation Among Young People', Political Quarterly, 74 (2003), 349-60. 
little attention to the more recent critical literature about the limits of political participation research and, in particular, make no reference to the work of Henrik Bang which is the focus here. ${ }^{5}$

Henrik Bang's work represents an interesting development in the political participation literature because it acknowledges the weaknesses of the existing literature and seeks to move beyond it. ${ }^{6}$ Unfortunately, in our view it has been insufficiently considered. ${ }^{7}$ Bang contends that most of the mainstream political participation literature focuses on what can be viewed as a 'free-rider' problem: people don't participate, but they do 'enjoy' the benefits of citizenship. ${ }^{8}$ In crude terms, the view is that the key problem lies with the citizens, rather than the state; they are apathetic and need to be encouraged to participate. However, this view reflects the weaknesses in the literature that Marsh, O'Toole and Jones identify. ${ }^{9}$

As we shall see in more detail below, Bang urges us to move beyond this focus on the free-rider problem towards a focus upon exclusion. In his view, citizens are not apathetic; rather, they are alienated from a political system which does not allow them a 'real', that is effective, voice. Consequently, if they participate, they do it on their own terms, rather than on terms established by the state. As such, Bang argues that contemporary liberal democracies are characterized, not by increasing political apathy, but by different types/forms of political participation. This is an interesting and important argument. However, it has not been effectively tested empirically and that is the aim of this article.

This article is divided into four main sections: the first section introduces, and briefly critiques, Bang's work, to pave the way for our own approach and empirical analysis; the

5 They make only one reference to Marsh, O'Toole and Jones's work, but almost wilfully misunderstand it. See Pattie, Seyd and Whiteley, Citizenship in Britain, p. 76, fn. 1, and for a reply, see Marsh, O’Toole and Jones, Young People and Politics, pp. 24-5.

${ }^{6}$ See, among others, H. Bang and E. Sorensen, 'The Everyday Maker: Building Social rather than Political Capital', in P. Dekker and E. Uslaner, eds, Social Capital and Participation in Everyday Life (London: Routledge, 2001), pp. 148-61; H. Bang, 'A New Ruler Makes a New Citizen: Cultural Governance and Everyday Making', in H. Bang, ed., Governance as Social and Political Communication (Manchester: Manchester University Press, 2003), pp. 241-66; H. Bang, 'Everyday Makers and Expert Citizens: Building Political not Social Capital' (unpublished paper, ANU School of Social Science, 2004); H. Bang, 'Among Everyday Makers and Expert Citizens', in J. Newman, ed., Remaking Governance: Peoples, Politics and the Public Sphere (Bristol: The Policy Press, 2005), pp. 159-79.

7 This is not to say that it has received no attention. Rather, it has been seized upon by authors from various countries and disciplines who are concerned with broader issues of governance. See, for example: M. Bevir, 'Government and Interpretation: What are the Implications of Postfoundationalism?' Public Administration, 82 (2004), 605-25; M. Bevir and R. Rhodes, 'Studying British Government: Reconstructing the Research Agenda', British Journal of Politics and International Relations, 1 (1999), 215-39; M. Blanc and J. Beaumont, 'Local Democracy within European Urban Development Programmes', Social and Economic Geography, 96 (2005), 409-20; P. Bogason and J. Musso, 'The Democratic Prospects of Network Governance', American Review of Public Administration, 36 (2006), 3-18; R. Edmondson, 'Social Capital: A Strategy for Enhancing Health?' Social Science and Medicine, 57 (2003), 1723-33; F. Forno and L. Ceccarini, 'From the Street to the Shops: The Rise of New Forms of Political Actions in Italy', South European Society \& Politics, 11 (2006), 197-222; P. Mouritsen, 'What's the Civil in Civil Society? Robert Putnam, Italy and the Republican Tradition', Political Studies, 51 (2003), 650-68; R. Rhodes, 'Putting People Back into Networks', Australian Journal of Political Science, 37 (2002), 399-416; H. Tapio and K. Auli, 'Preconditions of Democratic e-governance? A Critical Approach', in Ari-Veikko Anttiroiko and Antti Kasvio, eds, e-City. Analysing Efforts to Generate Local Dynamism in the City of Tampere (Tampere: Tampere University Press, 2005), pp. 409-48; and L. Torpe, 'Social Capital in Denmark: A Deviant Case?' Scandinavian Political Studies, 26 (2003), 27-48.

${ }^{8}$ Here, Bang may be unfair to the best rational choice theorists, who do deal more effectively with the free rider problem, but we would argue that his critique does apply to Pattie, Seyd and Whiteley.

9 Marsh, O’Toole and Jones, Young People and Politics. 
second section discusses the dataset and methods we use; the third reports our findings; and the fourth summarizes the key findings relating them to our central research question.

\section{INTRODUCING BANG}

Bang, like others before him, acknowledges the individualization of politics and the decline of citizen-orientated participation, which many people associate with a 'thinning' of social and political community. ${ }^{10}$ More specifically, he identifies two versions of this argument. First, there is Putnam's view on what he terms the 'mysterious disengagement' ${ }^{11}$ Overall, Putnam's argument is that this weaker civil engagement will lead to weaker, less effective and less responsive government. Secondly, and in contrast, the work of Norris and of Pattie, Seyd and Whiteley highlights the growth of new forms of participation: what Norris calls 'cause-orientated' participation. So, Pattie, Seyd and Whiteley argue that atomization is reflected, not in broad disengagement, but rather in a decline in collective participation and a rise in individualized or micro-political participation. ${ }^{12}$

However, to Bang, these approaches share two assumptions: first, that citizen participation is aimed at influencing the decisions of public authorities; and, secondly, that the core of citizen identity revolves around 'the creation of strong, affective moral ties, committing citizens to act normatively, responsibly and in the name of the common good'. ${ }^{13}$ In Bang's view, this inevitably means that, from this perspective, the key problem that an atomized citizenry raises for liberal democracies is a free-riding problem.

In contrast, while Bang does not doubt that free-riding is a problem, he does not see it as the key problem. In his view, individualization leads to more than atomization. More broadly, there is not just one core political problem for democracy - but rather ever-changing problems and challenges that stem from diversity, and this diversity is the key to understanding democracy. To Bang, participation involves 'the matching of political power and values in the situated interaction between political authorities and laypeople'. ${ }^{14}$ He argues, and this is absolutely crucial to his position, that 'a democratic political relationship of authority ... is one where everybody has the right and the possibility to make a difference to the constitution of politics and policy.' This leads him to make a distinction between political and social solidarity: political solidarity is thinner and, crucially, not based on any conception of the common good. All you need for political solidarity is that: "each and everybody in a political authority relationship hold the general political value that democracy requires the mutual acceptance and recognition of difference'. ${ }^{15}$

Given this view, Bang argues, the crucial problem of contemporary politics is political exclusion, rather than 'free-riding'. What is occurring is the uncoupling of the political authorities from what he terms 'the laypeople' and a consequent undermining of the political system. The increased complexity of late-modernity makes governing much more

10 Bang, 'Everyday Makers and Expert Citizens', p. 1.

11 Robert Putnam, 'Bowling Alone: America's Declining Social Capital', Journal of Democracy, 6 (1995), 65-78; 'Tuning In, Tuning Out: The Strange Disappearance of Social Capital in America', PS: Political Science and Politics, 28 (2005), 664-83; 'The Strange Disappearance of Civic America', American Prospect, 24 (1996), 34-48; Bowling Alone: The Collapse and Revival of American Community (New York: Simon \& Schuster, 2000).

12 Pattie, Seyd and Whiteley, Citizenship in Britain, chap. 3, especially Table 2.3, p. 81.

13 Bang, 'Everyday Makers and Expert Citizens', p. 3.

14 Bang, 'Everyday Makers and Expert Citizens', p. 3.

15 Bang, 'Everyday Makers and Expert Citizens', p. 4. 
difficult and the reaction of politicians, bureaucrats and corporatist interests is to exclude some groups/individuals, that is laypeople, from the process of deliberation. The weakest and the most vulnerable are the most excluded from the local, national and global level. Yet, political authorities 'cannot make and implement authoritative decisions for a society unless laypeople accept them and recognise themselves as bounded by them'. ${ }^{16}$

In this context, Bang sees two new political identities as emerging as the response of laypeople to the uncoupling problem: Expert Citizens; and Everyday Makers. Crucially, Expert Citizens and Everyday Makers do not have a legitimating or an oppositional role in relation to political authorities. Indeed, their political participation is not focused upon the state (i.e., they do not engage in state-driven or society-driven activity), but rather they engage in building and running governance networks and reflexive political communities, either full-time (as Expert Citizens) or part-time (as Everyday Makers).

Overall, to Bang, as the world is changing, so are the patterns of participation. Expert Citizens and Everyday Makers are the two new types of political participants which share certain characteristics, but are also very different.

\section{The Expert Citizen}

These are most often new professionals, particularly in voluntary organizations, but not within political parties, trade unions or private firms, who feel they can do politics and make and implement policy as well as the old authorities. They deal with all types of elites and sub-elites, both political and corporatist. In fact, Bang suggests, many Expert Citizens were previously grassroots activists. Expert Citizens thus need:

- a wide conception of the political as a discursive construct

- a full-time, overlapping, project identity reflecting their overall lifestyle

- the necessary expertise for exercising influence in elite networks

- to place negotiation and dialogue before antagonism and opposition

- to consider themselves as part of the system, rather than external and oppositional to it.

To Expert Citizens, politics is a fusion between representation and participation in a new form of political participation where you use your knowledge, skills and strategic judgement to influence others. Expert Citizens build networks of negotiation and co-operation with politicians, administrators, interest groups and the media; they develop 'network consciousness'. As compared with when they were grassroots activists, they have a weakening antagonism to the system; their aim is to make it an effective partner. Consequently, Expert Citizens are also a resource or political capital for democracy. In particular, they have a fund of everyday experience about how to deal with problems of exclusion based on ethnicity, gender, class/poverty etc.

\section{The Everyday Maker}

In many ways, Bang argues, the Everyday Maker is a response to the Expert Citizen. Everyday Makers do not feel defined by the state; they are neither apathetic about, nor opposed to, it. They do not want to waste time getting involved with the state; they prefer to be involved at the lowest possible, local, level. Everyday Makers typically think

${ }^{16}$ Bang, 'Everyday Makers and Expert Citizens', p. 4. 
globally, but act locally. They have no interest in producing a new form of interest representation and have minimal interest in party politics. They are also sceptical of new Expert Citizens because they pursue their own interests: 'They (Everyday Makers) draw a clear distinction within the realm of politics between elite networks and their own politics of the ordinary in the locality'. ${ }^{17}$ Similarly, they are not driven by a sense of duty, nor are they interested in gaining influence; rather, they wish to feel involved and develop themselves. They aim to encourage what Bang terms 'small local narratives'. Unlike the Expert Citizens, they don't want to mould identity; this, in particular, leads to conflict between Expert Citizens and Everyday Makers on the ground.

Bang argues that Everyday Makers live by a credo of everyday experience: ${ }^{18}$

-Do it yourself

-Do it where you are

-Do it for fun, but also because you find it necessary

-Do it ad hoc or part-time

-Do it concretely, instead of ideologically

-Do it with self-confidence and show trust in yourself

-Do it with the system, if need be.

Like Expert Citizens, Everyday Makers do not believe that representative democracy can be rescued, either by steering from above or accumulating social capital from below. In their view, there is a practical alternative to Putnam's notion of 'strong government' and 'thick community'. Everyday Makers are likely to vote and to be informed about 'high politics', but they do not get their political identities from being citizens of the state or members of an interest group or a social movement. They (like Expert Citizens) are concerned to enhance their personal capacities for self-governance and co-governance. In Bang's view: "They prefer a "thin" form of democratic political community that allows for the reciprocal acceptance and recognition of difference. They also consider "strong", effective and responsive government from above as a permanent threat to their selfgovernance and co-governance'. ${ }^{19}$

For our present purposes, the main thrust of Bang's work is his putative identification of these two new types of participant. He argues both that these new forms of political participation reflect key changes in society and that they will lead to changes in the nature of liberal democracies like Britain. These are big questions that deserve attention and one of us has, to an extent, engaged with these issues elsewhere ${ }^{20}$ However, there are, of course, a number of prior questions which inform our analysis here:

-Does Bang's classification of new forms of political participation exhaust all the possibilities?

- Is it possible to identify a significant number of Expert Citizens and Everyday Makers in a liberal democracy like Britain?

-If so, what leads people to become involved in the different forms of participation?

-Do these different types of participant have different relationships to the political system, more specifically, different levels of political trust and efficacy, and different levels of contact (with public officials) and voice (for the expression of disaffection) in the interests of public affairs?

17 Bang, 'Everyday Makers and Expert Citizens', p. 24.

18 Bang, 'Everyday Makers and Expert Citizens', p. 28.

19 Bang, 'Everyday Makers and Expert Citizens', p. 26.

${ }^{20}$ Marsh, O’Toole and Jones, Young People and Politics, pp. 46-51, 93-5, 101-10 and 215-17. 
This article is concerned with these questions. The first question is conceptual, as well as empirical, and is dealt with in the next sub-section. The other three questions are empirical and form the core of our analysis.

\section{BEYOND BANG}

There are a number of criticisms of Bang's work, but two are particularly important here because they partly inform our empirical work. ${ }^{21}$ First, in our view, it is implausible to focus, as Bang does, effectively on Expert Citizens and Everyday Makers only, although implicitly in his account there is recognition of a category of people active in conventional politics. In particular, while we would agree that most literature overplays nonparticipation and apathy, there are people who are very unlikely to participate under any circumstances. Secondly, Bang's category of Everyday Makers is difficult to operationalize, at least in quantitative terms. To Bang, Everyday Makers move in and out of politics, so if they are not involved in politics at a given time we do not know if that is because they are inactive Everyday Makers. As such, to undertake a quantitative analysis it is essential to know whether a person is currently or has previously been engaged. As such, we identify four types of participant which we specify below: Political Activists, Expert Citizens, Everyday Makers and Non-Participants. Secondly, Bang says nothing about the demographic characteristics of Expert Citizens and Everyday Makers, although the literature makes it clear that education, class, gender, age and ethnicity are, to varying extents, related to levels or types of socio-political participation.

Here, in the light of the general political participation literature, two points are important. First, although minority ethnic groups now constitute a significant proportion of the population, around 8 per cent in the 2001 Census, ${ }^{22}$ and faith groups, particularly Muslims, are increasingly important politically, there has been little discussion of the relationship between political participation and ethnicity or faith. For instance, because of their small sample size $(N=3,145)$, Pattie, Seyd and Whiteley only conducted binary analysis on ethnicity and religion (White/Non-White, and Religious/Non-Religious). In contrast, Fahmy used the same dataset as we do here, but still collapsed ethnicity into four groups (White, Black, Asian and Other) and undertook no analysis of faith groups. ${ }^{23}$ Given the large amount of research evidence on ethnic diversity and ethnic disadvantage, a more comprehensive analysis is overdue, ${ }^{24}$ and we undertake that here. Secondly, although there

${ }^{21}$ See Marsh, O’Toole and Jones, Young People and Politics.

22 A. Heath and S. Cheung, 'Ethnic Minority Disadvantage in the Labour Market: Britain', in A. Heath and S. Cheung, eds, Ethnic Differences Across Countries (Oxford: Oxford University Press, 2007).

${ }^{23}$ E. Fahmy, 'Ethnicity, Citizenship and Political Participation in Britain: Findings from the 2001 Home Office Citizenship Survey' (University of Bristol: Citizenship and Attitudes to Government in Britain: Project Working Paper 3, 2004).

${ }^{24}$ Much research has shown significant differences in various important aspects of life chances between ethnic groups. See, for example, V. Karn, ed., Ethnicity in the 1991 Census (London: The Stationery Office, 1997); F. Carmichael and R. Woods, 'Ethnic Penalties in Unemployment and Occupational Attainment: Evidence for Britain', International Review of Applied Economics, 14 (2000), 71-98; A. White, Social Focus in Brief: Ethnicity (London: Office for National Statistics, 2002); Y. Li, 'Social Capital, Ethnicity and the Labour Market', Proceedings on Engaging Community < http://engagingcommunities2005.org/abstracts/Li-Yaojun-final.pdf, $2005>$; Y. Li, 'Samples of Anonymised Records (SARs) from the UK Censuses: A Unique Source for Social Science Research', Sociology, 38 (2004), 553-72. 
has been a strong tradition of class analysis of voting in Britain, ${ }^{25}$ the utility of class as an explanatory variable has been heavily challenged in recent years. For example, Pakulski and Waters have proclaimed 'the death of class,' while Beck and Beck-Gernsheim see it as a 'zombie category'. ${ }^{26}$ Given that we are highly critical of that position, ${ }^{27}$ class features strongly in our analysis.

\section{DATA AND METHODS}

As we have argued, Bang's work is interesting, but, to date, it has not been systematically tested. Bang himself undertook a study of political participation in Inner Noerrebro, an area of Copenhagen, Denmark, which historically was a stronghold of left-wing parties and grassroots movements fighting the system. ${ }^{28}$ This led to the development of his ideas on the new types of political participation. Similarly, Marsh, Jones and O'Toole used their data on political participation in Birmingham, England, to try to establish whether there were Everyday Makers among their respondents. ${ }^{29}$ However, both studies are qualitative. Here, the aim is different. We use the best and most relevant data to establish in quantitative terms whether we can identify Expert Citizens and Everyday Makers among the respondents; if we can, how these groups, and our Political Activists and Non-Participants differ, if at all, in terms of socio-demographic characteristics; and what effects these different types of political participant have upon levels of political trust and efficacy on the one hand, and of contact and voice on the other (see below for details of the two domains).

We need to make it clear from the outset that we do not claim to have produced a foolproof empirical test of Bang's arguments and, indeed, we explore the limitations of our data below. Rather, our modest claim is that we used the best data available and developed Bang's notions in a way which is conceptually vigorous and empirically testable. As such, the merit of this piece stands, or falls, on whether the reader thinks Bang's work and, more importantly, our development of it, is important enough to deserve examining empirically and, if it is, whether our analysis provides a useful, if imperfect, examination. We have already given our answer to the first question, namely, that in our view, Bang's work is important and deserves rigorous empirical (quantitative) investigation. The second question needs a more detailed consideration and we return to it once we have introduced our data and outlined our analytical framework.

${ }^{25}$ See, for instance, A. Heath, R. Jowell and J. Curtice, How Britain Votes (Oxford: Pergamon, 1985); A. Heath, R. Jowell and J. Curtice, The Rise of New Labour: Party Politics and Voter Choices (Oxford: Oxford University Press, 2001); R. Andersen and A. Heath, 'Class Matters: The Persisting Effects of Contextual Social Class on Individual Voting in Britain, 1964-97', European Sociological Review, 18 (2002), 125-38; J. Goldthorpe, 'Class and Politics in Advanced Industrial Societies', in D. Lee and B. Turner, eds, Conflict about Class: Debating Inequality in Late Industrialism (London: Longman, 1996), pp. 196-208; G. Evans, ed., The End of Class Politics? Class Voting in Comparative Context (Oxford: Oxford University Press, 1999).

${ }^{26}$ J. Pakulski and M. Waters, The Death of Class (London: Sage, 1996); U. Beck and E. Beck-Gernsheim, The Normal Chaos of Love (Cambridge: Polity, 1995).

27 See Marsh, O'Toole and Jones, Young People and Politics, chap 5.

${ }^{28}$ Reported in Bang and Sorensen, 'The Everyday Maker', and Bang, 'Everyday Makers and Expert Citizens'.

${ }^{29}$ Marsh, O’Toole and Jones, Young People and Politics, chap 4. 


\section{The Data}

There are no extant data specifically designed to test Bang's arguments. Consequently, we had to decide if there was any dataset which allowed us to examine Bang's analysis, even if in a less than perfect way. After some consideration, we decided to use the 2001 Home Office Citizenship Survey (HOCS). The survey contains a total of 15,475 respondents (a core sample of 10,015 respondents and a minority ethnic boost sample of 5,460 respondents) aged 16 and over and resident in private households in England and Wales at the time of interview. ${ }^{30}$ The HOCS has rich data on, among other things: socio-demographic attributes; types of formal and informal political participation from which we can construct our political participation variable; trust in different political institutions; feelings of efficacy at local and national levels; contact with public officials; and voicing of dissatisfaction with politics and politicians. ${ }^{31}$ Given the large sample size, especially as regards ethnic and faith groups, and the very rich socio-cultural and political participation data, we believe that the HOCS is a better dataset than that provided by other British datasets on political participation, including that of Pattie, Seyd and Whiteley.

\section{The Analytical Framework}

Our purpose in this article is to explore the main determinants of the various forms of political participation/types of political participant and their impact upon political trust/efficacy and, in turn, upon political contact and voice. For this purpose, we shall be using types of political participant first as an outcome and then as an explanatory variable. In the first stage of our analysis the aim is to explain why individuals become involved in different forms of participation. Here, the explanatory variables we use are the ones that previous research on social capital ${ }^{32}$ and on political participation has identified as important: age, sex and marital status as demographic variables; ethnicity and religion as cultural variables; and class and educational qualifications as social stratification variables. ${ }^{33}$ This is shown by arrow 1 in Figure 1.

${ }^{30}$ We shall use the terms 'Britain' and 'British' as shorthand in the following discussion, although we do not necessarily mean that the patterns revealed in the data can be generalized to Scotland. For a similar practice, see J. Goldthorpe (with C. Llewellyn and C. Payne), Social Mobility and Class Structure in Modern Britain (Oxford: Clarendon Press, 1987).

${ }^{31}$ More details of the survey, including the questionnaire, coding and weighting schemes, can be found at $<$ http://www.data-archive.ac.uk/findingData/snDescription.asp?sn $=4754 \#$ doc $>$. See also C. Attwood, G. Singh, D. Prime, R. Creasey and others, 2001 Home Office Citizenship Survey: People, Families and Communities (London: Home Office Research, Development and Statistics Directorate, 2003).

${ }^{32}$ P. Hall, 'Social Capital in Britain', British Journal of Political Science, 29 (1999), 417-61; P. Paxton, 'Is Social Capital Declining in the United States? A Multiple Indicator Assessment', American Journal of Sociology, 105 (1999), 88-127, and 'Social Capital and Democracy: An Interdependent Relationship', American Sociological Review, 67 (2002), 254-77; Putnam, Bowling Alone; Y. Li, M. Savage and A. Pickles, 'Social Capital and Social Exclusion in England and Wales (1972-1999)', British Journal of Sociology, 54 (2003), 497-526; Y. Li, A. Pickles and M. Savage, 'Social Capital and Social Trust in Britain', European Sociological Review, 21 (2005), 109-23; Y. Li 'Social Capital, Social Exclusion and Public Health', in A. Scriven and G. Sebastian, eds, Public Health: Social Context and Action (London: Sage, 2007).

${ }^{33}$ There is no unanimous agreement on the terminology of these variables. For instance, 'sex' can be regarded as a demographic or a social attribute. Similarly, ethnicity and religion can be viewed as cultural or demographic. Education is sometimes used as an indicator of cultural capital (A. Sullivan, 'Cultural Capital and Educational Attainment', Sociology, 35 (2001), 893-912) and sometimes as part of social stratification factors (T. Chan and J. Goldthorpe, 'The Social Stratification of Theatre, Dance and Cinema Attendance', Cultural Trends, 14 (2005), 193-212). We do not wish to get embroiled into any terminological debates and we just use these terms in the conventional sense. 


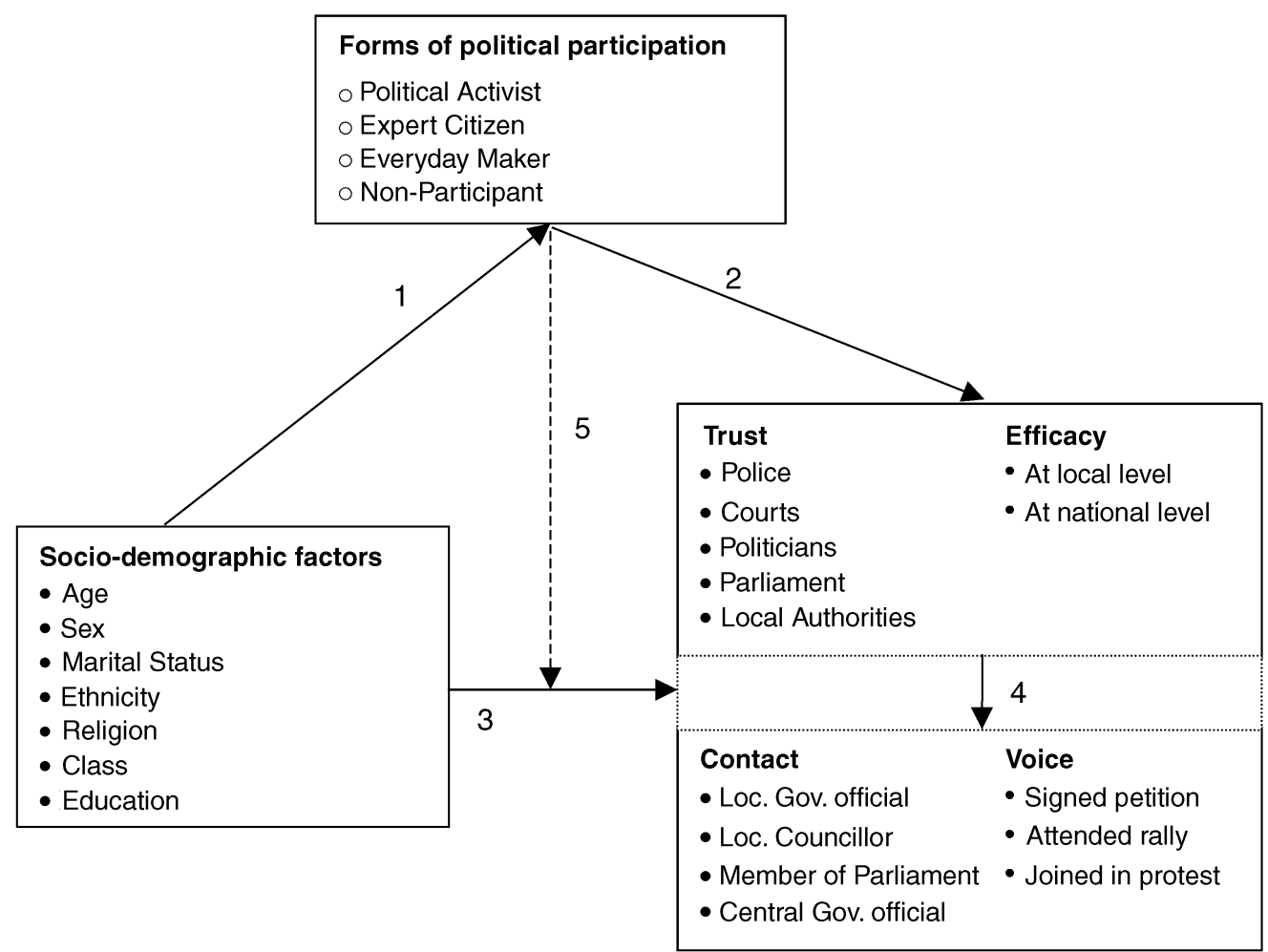

Fig. 1. Forms of political participation, their socio-cultural determinants and impacts on political trust/efficacy and on political contact/voice

Note: Solid lines denote direct effects and dotted lines denote moderator effects. Solid circles refer to variables and empty circles refer to categories.

Existing research has also shown that political participation is related to political efficacy $^{34}$ and trust, though in the latter case the direction of the relationship is subject to debate. ${ }^{35}$ This relationship is represented by arrow 2 in Figure 1 . At the same time, it seems sensible to propose that different forms of participation will be related to the extent of contact with public officials and to the voicing of disaffection with politics and politicians, and that trust and efficacy will also play a part in the process (see arrow 4). Socio-demographic factors may also have considerable impact on trust/efficacy and on contact/voice, as represented by arrow 3. Finally, as some social-demographic groups involved in particular forms of participation may have political beliefs/behaviour that are different from their peers involved in other forms of participation, we aim to capture this, where appropriate, by assessing the interaction effects, as represented by arrow 5 . Our analysis investigates each of these hypothesized relationships. The main effects (arrows 1-4) will be presented in tables and discussed in text, with the interaction effects (arrow 5) discussed in text or footnotes, to avoid making the tables too complex.

\footnotetext{
${ }^{34}$ Fahmy, 'Ethnicity, Citizenship and Political Participation in Britain'.

35 Putnam, Bowling Alone.
} 


\section{Specifying the Variables}

The key problem we have is whether the data allow us adequately to specify the categories of our main variable of interest, namely, forms of political participation, in a way which does enough justice to Bang's arguments and which enables us to develop his ideas.

Of course, there are always limitations in mapping quantitative data on to conceptual notions and using data not purposely designed to examine the concepts in which one is interested. Here, the specific problem is that the HOCS data in the main only allows us to identify the structural characteristics of Expert Citizens and Everyday Makers, not the attitudinal ones. So, we can identify what type of participation the respondents are involved in, and whether that activity fits broadly well with Bang's discussion of the 'new' forms of participation, but we cannot ascertain what the respondents were thinking and how they were feeling about their participation. For example, we do not know whether the respondents participated for concrete or instrumental, rather than ideological, reasons, or whether they were doing it with self-confidence or for fun, both of which are, according to Bang, key features of the participation of Everyday Makers. However, to reiterate, there is no dataset which would allow us fully to tap into those aspects of Bang's thesis and we would argue that our specifications capture enough of Bang's distinctions to be empirically useful.

As such, the construction of the participation variable proceeded as follows. In the 2001 HOCS, there are data on current (in the previous twelve months) formal involvement in terms of 'group, club or organisation'. Questions were asked of such involvement in fifteen organizations [V3.1f] covering: (1) children's education/schools; (2) youth/children's activities (outside school); (3) education for adults; (4) sports/exercise; (5) religion; (6) politics; (7) health, disability and social welfare; (8) the elderly; (9) safety, first aid; (10) the environment, animals; (11) justice and human rights; (12) local community or neighbourhood groups; (13) citizen's groups; (14) hobbies/recreation/arts/social clubs; and (15) trade-union activity. Within each of these organizations, there were further questions on eleven fields of interest [V3.2b] covering: (1) raising or handling money; (2) leading the group/member of a committee; (3) organizing or helping to run an activity or event; (4) visiting/befriending people; (5) giving advice/information/counselling; (6) secretarial, administrative or clerical work; (7) providing transport/driving; (8) representing; (9) campaigning; (10) other practical help; and (11) any other help. Moreover, the sector [V3.7] of the organization that the volunteers had helped was also asked: (1) public sector; (2) private sector; (3) voluntary and community sector; and (4) other. For respondents who were not currently involved but who had been involved more than twelve months ago, the same questions were asked on the eleven fields of interest in their previous formal involvement [V5.1].

Using these codes, we constructed our participation variable with four categories as shown in Figure 1. First, we specified Political Activists as those involved in what one might call conventional politics, namely, those who are currently engaged in organizations characterized by politics or trade-union activity (category 6 or 15 in V3.1f). ${ }^{36}$ Secondly, in the remaining sample, we specified Expert Citizens as those who acted in the capacity

\footnotetext{
36 There is no data on voting, but as far as Bang is concerned, Expert Citizens and Everyday Makers are not less likely to vote than other participants. We would also stress here that we do have a narrow definition of standard political participators, but that reflects the existing literature and the whole point about the article is that we also differentiate two other types of participator as the focus of the article, namely, Expert Citizens and Everyday Makers.
} 
of leaders or representatives in terms of fields of interest in current or previous formal involvement (category 2 or 8 in V3.2b or V5.1) and, for those currently involved, who helped organizations that were outside the private sector (category 1, 3 or 4 in V3.7). Thirdly, Everyday Makers are defined as those who are currently or previously involved but not in the capacity of Political Activists or Expert Citizens as defined above. Finally, Non-Participants are those who did not volunteer in the last twelve months or over twelve months ago in any of the three activist capacities. ${ }^{37}$

As shown in Figure 1, we also explore the relationship between the types of political participant and two domains of political beliefs/actions: trust/efficacy; and contact/voice. Each of the two domains consists of two subsets with a differing number of variables. Trust is assessed in relation to police, courts, politicians, parliament and local authorities; efficacy refers to the feeling that one can influence decisions affecting the local and the national levels; contact involves contacting a public official working for the local council, contacting a local councillor, contacting a Member of Parliament, or contacting a public official working for the central government; and voice involves signing petitions, attending public meetings or rallies, or joining in public demonstrations or protests. ${ }^{38}$

We shall explore the association between our four groups of political participants and the two domains of political beliefs/actions in terms of both descriptive analysis and statistical modelling. With regard to modelling, as the space limit of this article does not allow us to present results for each of the fourteen variables in the two domains, we used techniques based on item response theory (IRT) ${ }^{39}$ to obtain latent variable scores for categorical indicator variables for each of the domains. ${ }^{40}$ The scores thus obtained were then standardized (with a mean of 0 and a standard deviation of 1 ) so that we could easily compare the relative effects of different socio-demographic attributes and of types of political participant.

We give a brief account here of the socio-demographic variables. Ethnicity is operationalized according to the 1991 Census as an eight-way variable: White, Black

37 The four groups of political participants were constructed by using a combination of questions on V3.1f, V3.2b, V3.7 and V5.1 in the 2001 HOCS. The details of the questions are available at < http://www.dataarchive.ac.uk/doc/4754/mrdoc/pdf/4754userguide1.pdf $>$ (last accessed on 12 October 2006) at pp. 150, 154, 157 and 162 respectively, including detailed definitions and explanations to the interviewers. Because of the space limit, we do not reproduce the details here but interested readers can easily find out. Twenty respondents who gave no valid information to these questions were dropped from analysis.

${ }^{38}$ See < http://www.data-archive.ac.uk/doc/4754/mrdoc/pdf/4754userguide1.pdf $>$ p. 148 on trust [V2.5]. Note that trust in employers, the Welsh Assembly and the Greater London Assembly are not analysed. Questions on efficacy are asked in [V2.4], available at p. 147. Again, efficacy on Wales and Greater London are not analysed. Questions on contact and voice are asked in [V2.1a-V2.1c], available at pp. 145-6. Responses in [V2.1a-V2.1c] specific to Wales or London are not analysed. All the explanations to the questions are also available in these pages. The instructions to the respondents and to the interviewers made it clear that these questions are about 'public affairs' and thus contact for personal issues or contact through work is not to be coded.

${ }^{39}$ See Appendix 2 (available at < http://www.ccsr.ac.uk/staff/yaojun.htm $>$ ) for a brief discussion of the IRT modelling. For a classical account, see F. Lord and M. Novick, Statistical Theories of Mental Test Scores (Boston, Mass.: Addison-Wesley, 1968). For a recent definitive account, see A. Skrondal and S. Rabe-Hesketh, Generalized Latent Variable Modeling: Multilevel, Longitudinal, and Structural Equation Models (London: Chapman \& Hall/CRC, 2004). See also Li, Pickles and Savage, 'Social Capital and Social Trust', for an application of the IRT modelling to social capital research.

${ }^{40}$ See D. Rubin, 'Inference and Missing Data', Biometrika, 63 (1976), 581-92; and B. Muthén, 'Latent Variable Analysis: Growth Mixture Modelling and Related Techniques for Longitudinal Data', in D. Kaplan, ed., Handbook of Quantitative Methodology for the Social Sciences (Newbury Park, Calif.: Sage Publications, 2004), pp. 345-68. 
Caribbean, Black African, Indian, Pakistani, Bangladeshi, Chinese and Other. ${ }^{41}$ Religion is also coded as an eight-way variable: Christian, Buddhist, Hindu, Jewish, Muslim, Sikh, Other and None. As such, our approach marks a significant step forward in the treatment of these variables in the political participation literature ${ }^{42}$ and our categories are not only sociologically more meaningful than those used in existing literature, but also operationally amenable to multivariate analysis.

Class is measured using a three-way Goldthorpe class schema, differentiating between the service class (professionals, administrators and managers), the intermediate class (petty bourgeois, routine non-manual, and forepersons and lower technicians) and the working class (skilled, semi-skilled and unskilled manual workers, including agricultural labourers). ${ }^{43}$ As the data are collected from people aged 16 and over, a sizeable number of our respondents are still in education and they are assigned to a separate category: students. Our focus in the following analysis is, however, on the contrast between the service and the working classes. As regards educational qualifications, we differentiated, on the basis of the respondent's highest qualification: first-degree or above; diploma/ A-levels; trade apprenticeships/O-levels; and primary/none.

In order to address the issues of unequal selection probabilities, differential non-response among subgroups and the over-representation of minority ethnic groups, we used the appropriate weighting variable for the individual-level analysis of the combined sample, with analytical weights in the descriptive, and probability weights in the inferential, analysis.

\section{ANALYSIS}

We present our findings following the procedure suggested in Figure 1. With regard to the association between socio-demographic factors and forms of political participation (arrow 1), the issue not considered by Bang, we present a general picture, before looking at the results in terms of net effects. Subsequently, we shall look at the latent factor scores for the two domains of political beliefs/actions and use them in the multivariate analysis to unpack the relative effects between forms of participation and socio-demographic factors.

The data in Table 1 show the association between the socio-demographic variables and forms of political participation. At the bottom of the table, we can see that, of the 15,454 respondents who gave information on political participation, 8.4 per cent are Political Activists, 15.0 per cent Expert Citizens and 37.3 per cent Everyday Makers. Thus, 60.7 per cent of the respondents were participating in forms of 'political' activities, while 39.3 per cent were Non-Participants.

With regard to the socio-demographic characteristics of the four groups of political participants, we find that age is a crucial factor in a predictable way. ${ }^{44}$ The middle-aged

\footnotetext{
${ }^{41}$ It is noted here that even though both Attwood et al., Home Office Citizenship Survey, and Fahmy, 'Ethnicity, Citizenship and Political Participation in Britain', use the same data as we do here, there are significant differences between their and our analyses. Attwood et al. were mainly interested in exploring the basic association as revealed in crosstabulations and were not focused on any particular theoretical or sociological theme (see, for instance, their Table 5.2 and associated discussions). Fahmy, as noted earlier, only used a four-way ethnic variable and did not analyse faith groups.

${ }^{42}$ Pattie, Seyd and Whiteley, Citizenship in Britain.

43 Goldthorpe, Social Mobility.

44 The result confirms the conclusion by Pattie, Seyd and Whiteley, Citizenship in Britain, that the middle-aged are more likely to participate, Table 3.4, p. 27.
} 
TABLE 1 Socio-demographic Characteristics of Political Participants (Percentage by Row)

\begin{tabular}{|c|c|c|c|c|c|}
\hline & $\begin{array}{c}\text { Political } \\
\text { Activist }\end{array}$ & $\begin{array}{l}\text { Expert } \\
\text { Citizen }\end{array}$ & $\begin{array}{l}\text { Everyday } \\
\text { Maker }\end{array}$ & $\begin{array}{c}\text { Non- } \\
\text { Participant }\end{array}$ & $N$ \\
\hline \multicolumn{6}{|l|}{ Age } \\
\hline $16-24$ & 3.9 & 11.2 & 44.1 & 40.8 & 1,813 \\
\hline $25-39$ & 8.9 & 14.0 & 40.3 & 36.8 & 5,152 \\
\hline $40-59$ & 11.7 & 18.1 & 35.2 & 35.0 & 4,657 \\
\hline $60+$ & 6.1 & 14.1 & 33.1 & 46.6 & 3,824 \\
\hline \multicolumn{6}{|l|}{ Sex } \\
\hline Male & 10.9 & 16.1 & 34.4 & 38.6 & 6,861 \\
\hline Female & 6.1 & 14.0 & 40.0 & 39.9 & 8,594 \\
\hline \multicolumn{6}{|l|}{ Marital status } \\
\hline Never married & 7.5 & 12.3 & 39.5 & 40.8 & 4,270 \\
\hline Married & 9.8 & 17.2 & 37.1 & 35.9 & 7,552 \\
\hline Once married & 5.6 & 12.4 & 34.6 & 47.4 & 3,617 \\
\hline \multicolumn{6}{|l|}{ Ethnicity } \\
\hline White & 8.6 & 15.7 & 37.4 & 38.7 & 9,353 \\
\hline Black Caribbean & 6.1 & 10.8 & 38.0 & 45.2 & 1,004 \\
\hline Black African & 8.3 & 15.5 & 33.2 & 43.1 & 703 \\
\hline Indian & 5.3 & 7.5 & 36.8 & 50.3 & 1,332 \\
\hline Pakistani & 3.9 & 8.4 & 28.9 & 58.8 & 945 \\
\hline Bangladeshi & 2.9 & 10.9 & 27.5 & 58.7 & 580 \\
\hline Chinese & 2.6 & 11.1 & 41.7 & 44.7 & 148 \\
\hline Other & 4.9 & 9.9 & 36.4 & 48.8 & 1,390 \\
\hline \multicolumn{6}{|l|}{ Religion } \\
\hline Christian & 8.2 & 15.5 & 37.4 & 38.9 & 9,271 \\
\hline Buddhist & 7.7 & 19.0 & 29.0 & 44.4 & 110 \\
\hline Hindu & 5.4 & 8.2 & 39.2 & 47.1 & 778 \\
\hline Jewish & 7.0 & 34.0 & 30.9 & 28.1 & 51 \\
\hline Muslim & 3.9 & 9.1 & 27.3 & 59.7 & 2,195 \\
\hline Sikh & 3.9 & 6.1 & 37.4 & 55.3 & 388 \\
\hline Other & 11.9 & 16.8 & 33.9 & 37.4 & 469 \\
\hline None & 9.6 & 13.2 & 38.6 & 38.6 & 2,193 \\
\hline \multicolumn{6}{|l|}{ Class } \\
\hline Service & 12.8 & 21.6 & 40.5 & 25.0 & 4,062 \\
\hline Intermediate & 7.3 & 15.0 & 37.1 & 40.6 & 4,296 \\
\hline Working & 6.1 & 8.3 & 32.8 & 52.9 & 5,943 \\
\hline Student & 4.7 & 16.4 & 44.9 & 34.0 & 1,154 \\
\hline \multicolumn{6}{|l|}{ Education } \\
\hline Degree + & 14.6 & 25.3 & 40.4 & 19.8 & 2,519 \\
\hline Diploma/A Level & 11.3 & 17.3 & 42.5 & 28.9 & 3,314 \\
\hline Trade app/O Level & 7.0 & 14.0 & 38.0 & 41.0 & 4,218 \\
\hline Primary/None & 4.2 & 8.3 & 30.6 & 56.9 & 5,404 \\
\hline$A l l$ & 8.4 & 15.0 & 37.3 & 39.3 & 15,454 \\
\hline
\end{tabular}

Note: The combined (core and minority ethnic boost) sample is used in this and subsequent tables, with weighted percentages (or coefficients in modelling tables) and unweighted respondents.

Source: The 2001 Home Office Citizenship Survey is the source for this and the other tables. 
are much more likely than the other age groups to be a Political Activist or Expert Citizen. The younger groups are more likely to be rank-and-file followers (Everyday Makers), whilst the oldest group are most likely to be absent from involvement. The pattern here echoes recent research findings that young people in Britain are more engaged in loosely-knit social connections than in formal civic organizations. ${ }^{45}$ Gender differences are less pronounced, although men (10.9 per cent) are somewhat more likely than women (6.1 per cent) to be Political Activists and women are similarly more likely than men to be Everyday Makers. The noticeable differences with regard to marital status manifest themselves in two aspects. ${ }^{46}$ First, married people are generally more likely than the non-married (never married or once married) to be Political Activists or Expert Citizens. Secondly, the once married (widowed, divorced and separated) are most likely to be in the Non-Participant category, which is probably a reflection of their age profile. Indeed, further analysis shows that over half of the once married are over 60 years of age.

As pointed out earlier, owing to the lack of data, studies of political participation in Britain have had relatively little to say about ethnic or religious background. We have the first data that can fully explore that relationship. Our analysis here shows some interesting features. First, there seem to be more ethno-religious differences than ones based on age, gender or marital status. ${ }^{47}$ With regard to ethnicity, among the minority groups people of Black African origin are most likely to be Political Activists and Expert Citizens (8.3 and 15.5 per cent respectively), and people of Chinese origin are most likely to be Everyday Makers (41.7 per cent), whilst people of Pakistani and Bangladeshi origins are most likely to be Non-Participants (nearly 59 per cent each). With regard to religion, people of Jewish descent are by far the most likely to be Expert Citizens ( 34 per cent), as compared with the 6.1 per cent of the Sikhs. Muslims and Sikhs are the least likely to be political participants (59.7 and 55.3 per cent respectively). There is, of course, a close association here and further analysis shows that 97 per cent of the respondents of Pakistani and Bangladeshi origins are Muslims, while 13 per cent of the respondents of Indian origin are also Muslims.

Class and educational differences have a far more pronounced effect than the other personal attributes considered to date and, interestingly, the effect of class is much greater than reported by Pattie, Seyd and Whiteley. ${ }^{48}$ Thus, 34.4 per cent of the respondents in the service class were 'Political Activists' or 'Expert Citizens,' as compared with only 14.4 per cent of the working class. On the other hand, nearly 53 per cent of the latter and only 25 per cent of the former were in the Non-Participant group. Certainly, class seems to

\footnotetext{
45 Y. Li, M. Savage and A. Warde, 'Social Stratification' (unpublished paper, Institute for Social Change, University of Manchester). There are also data in the HOCS on informal help, namely, unpaid help given to non-relatives in the last twelve months, in [V6.1] < http://www.data-archive.ac.uk/doc/4754/mrdoc/pdf/ 4754userguide1.pdf $>$ at p. 165. Further analysis shows that around 72.4 per cent of the two younger groups gave one kind or another of unpaid informal help to non-relatives, as compared with 56.8 per cent of the oldest group.

${ }^{46}$ The conceptual link between marital status and participation lies in the fact that some of the fifteen organizations have a very close bearing on family life. As married people are more likely to have children and to be residentially stable than the never married or the once married, they are more involved in children's education/schools and/or in neighbourhood groups. Further analysis confirms this (details are available on request).

47 Further analysis confirms this. Putting all the socio-demographic factors in the table as explanatory variables and political participation as the outcome variable in an ordinal logit regression analysis, we find that the ethno-religious variables yield greater chi-square values $\left(\chi^{2}=158.89\right.$ with 14 degrees of freedom) than do the age-sex-marital variables $\left(\chi^{2}=90.09\right.$ with 6 degrees of freedom), and the difference between the two sets of variables is statistically significant at the 0.05 level $\left(\chi^{2}=10.45\right.$ with 1 degree of freedom, $\left.p=0.001\right)$.

${ }^{48}$ Pattie, Seyd and Whiteley, Citizenship in Britain, Table 3.4, p. 86 and Table 6.12, p. 182.
} 
matter here. The differences between the educational groups are even starker. People with degree or higher qualifications are around three times more likely than those with only primary or no formal educational qualifications to be Political Activists or Expert Citizens (39.9 as against 12.5 per cent), and the latter are similarly more likely than the former to be Non-Participants (nearly 57 as against nearly 20 per cent).

We have described the association between socio-demographic groups and forms of political participation. However, many of these variables are obviously interrelated. ${ }^{49}$ In order to see the net effects, we show, in Table 2, results of a multinomial logit regression. ${ }^{50}$ We used 'Non-Participants' as the base group and each of the other groups - Political Activists, Expert Citizens and Everyday Makers - is contrasted with Non-Participants. We find that the patterns generally reinforce those that emerged in Table 1. Holding constant all other variables in the model, we find the younger cohorts less likely to be involved in traditional politics (party politics or trade unions where the 40-59 cohort takes a prominent role) or to assume formal leadership roles, but much more likely to be Everyday Makers. ${ }^{51}$ Women are less likely than men to partake in conventional politics but more likely to be engaged in other capacities, particularly as rank-and-file participants. It is also noted here that statistical modelling can reveal patterns which would remain obscure, or hidden, in descriptive analysis. Thus, both the 'never-married' group and the 'once-married' group are, holding constant the other variables in the models, less likely than the married group to be in each of the three activist groups, a pattern barely noticeable in Table 1. Religion, rather than ethnicity, seems to be a more important factor underpinning participation. Thus, holding constant all other socio-demographic factors, Muslims are consistently less likely, and significantly so in two out of the three contrasts, to be in any of the activist group, whereas their ethnic origins did not make any marked difference. Indeed, further analysis shows that Muslims from India, Pakistan or Bangladesh were not significantly different in any of the three contrasts. With regard to Expert Citizens, it must be pointed out that the Jewish respondents were the most active, with the largest positive coefficient amongst all faith groups $(0.720){ }^{52}$

The most salient patterns in Table 2 concern class and education. Controlling for all other factors in the model, we find that class, and education in particular, have a very important effect. In terms of the magnitude of the coefficients, the differences between degree holders and those with least educational qualifications, and between the service and the working classes, are generally, and consistently, larger than those found for categories in the other variables. Another notable feature of Table 2 is that class effects are most strongly associated with Expert Citizens and educational effects with both Political Activists and Expert Citizens. Thus, controlling for all other variables in the models, the coefficients for the service class (as compared with the working class whose value is set at 0 in the model) are $0.510,0.943$ and 0.521 , and those for degree holders (as compared with the non-qualified) are 1.926, 1.852 and 1.067 respectively for Political Activists, Expert

\footnotetext{
${ }^{49}$ For instance, further analysis shows that over three quarters of those with degrees are found in the service class, whilst nearly 60 per cent of the least educationally qualified group are in the working class.

${ }^{50} \mathrm{We}$ also carried out an ordinal logit regression analysis as noted above on the assumption that the four categories take an inherent order such that 'Political Activists' have greater political capital than 'Expert Citizens' who in turn have greater political capital than 'Everyday Makers', etc. The patterns are the same but multinomial logit analysis discloses features not shown in ordinal logit analysis, hence, our preference for the former.

51 This confirms the conclusion of Pattie, Seyd and Whiteley, Citizenship in Britain, Table 3.4, p. 86.

52 Even though the coefficient did not reach the significance level $(p=0.24)$, we must remember that there are only fifty-one respondents of Jewish faith in the sample, as shown in Table 1.
} 
TABLE 2 Multinomial Logit Regression Coefficients for Political Participants (Contrasts with 'Non-Activists')

\begin{tabular}{|c|c|c|c|}
\hline & Political Activist & Expert Citizen & Everyday Maker \\
\hline \multicolumn{4}{|l|}{ Age } \\
\hline $16-24$ & $-0.766^{* *}$ & $-0.435^{*}$ & $0.285^{* *}$ \\
\hline $25-39$ & -0.036 & $-0.269 * *$ & $0.151 *$ \\
\hline $40-59$ & $0.489 * * *$ & $0.149 \dagger$ & $0.133 \dagger$ \\
\hline \multicolumn{4}{|l|}{$60+($ ref. $)$} \\
\hline \multicolumn{4}{|l|}{ Sex } \\
\hline Female & $-0.389 * * *$ & 0.028 & $0.249 * * *$ \\
\hline Male (ref.) & & & \\
\hline \multicolumn{4}{|l|}{ Marital status } \\
\hline Never married & -0.192 & $-0.457 * * *$ & $-0.304 * *$ \\
\hline Once married & $-0.443 * * *$ & $-0.314 * * *$ & $-0.189 * *$ \\
\hline Married (ref.) & & & \\
\hline \multicolumn{4}{|l|}{ Ethnicity } \\
\hline White (ref.) & & & \\
\hline Black Caribbean & $-0.381 *$ & $-0.371 *$ & -0.081 \\
\hline Black African & -0.234 & -0.227 & $-0.289 *$ \\
\hline Indian & -0.253 & $-0.602 * *$ & 0.020 \\
\hline Pakistani & -0.362 & -0.384 & 0.091 \\
\hline Bangladeshi & -0.439 & 0.121 & 0.133 \\
\hline Chinese & $-1.723 * * *$ & $-0.942 *$ & -0.265 \\
\hline Other & $-0.632 * *$ & $-0.597 * *$ & -0.072 \\
\hline \multicolumn{4}{|l|}{ Religion } \\
\hline Christian (ref.) & & & \\
\hline Buddhist & -0.164 & 0.092 & -0.488 \\
\hline Hindu & $-0.663 \dagger$ & $-0.566 *$ & -0.383 \\
\hline Jewish & -0.156 & 0.720 & -0.123 \\
\hline Muslim & $-0.628 *$ & -0.489 & $-0.789 * * *$ \\
\hline Sikh & $-0.884 *$ & $-0.782 *$ & $-0.593 * *$ \\
\hline Other & 0.199 & -0.019 & -0.173 \\
\hline None & 0.001 & $-0.247 *$ & -0.077 \\
\hline \multicolumn{4}{|l|}{ Class } \\
\hline Service & $0.510 * * *$ & $0.943 * * *$ & $0.521 * * *$ \\
\hline Intermediate & 0.018 & $0.541 * * *$ & $0.216 * * *$ \\
\hline Student & 0.259 & $1.233 * * *$ & $0.535 * * *$ \\
\hline Working (ref.) & & & \\
\hline \multicolumn{4}{|l|}{ Education } \\
\hline Degree + & $1.926 * * *$ & $1.852 * * *$ & $1.067 * * *$ \\
\hline Diploma/A Level & $1.478 * * *$ & $1.197 * * *$ & $0.803 * * *$ \\
\hline Trade app/O Level & $0.769 * * *$ & $0.803 * * *$ & $0.442 * * *$ \\
\hline \multicolumn{4}{|l|}{ Primary/None (ref.) } \\
\hline Constant & $-2.416 * * *$ & $-2.041 * * *$ & $-0.835 * * *$ \\
\hline Pseudo $R^{2}$ & 0.059 & & \\
\hline$N$ & 15,430 & & \\
\hline
\end{tabular}

Note: Weighted data with robust standard errors. Owing to the large amount of data presented, standard errors and 95 per cent confidence intervals are not shown but are available on request. (The same applies in the modelling tables below.) $\dagger p<0.10, * p<0.05$, ** $p<0.01$ and $* * * p<0.001$. 
Citizens and Everyday Makers. It is also worth noting that party politics and trade-union activities used to be home to working-class men in Britain but over the last thirty years, it has gradually shifted ground so that it has been increasingly, and is currently predominantly, composed of people in middle-class positions. ${ }^{53}$

A third important feature of Table 2 concerns the relatively weak political participation of some ethno-religious groups, when all other factors in the models are taken into account. For instance, people of Chinese origin are notably absent both from conventional politics and from assuming leadership roles in new forms of participation. Equally notable is the lack of participation by Muslim, Sikh and Hindu communities. Black Caribbeans are also underrepresented in party or trade-union activities, and in leadership roles of new forms of participation.

Of course, the results we present in Table 2 are main effects. As such, there may be interaction effects involved which our models did not investigate; that is, one may argue that it is not being Chinese, Muslim or Black per se which hinders respondents from being Political Activists, Expert Citizens or Everyday Makers, but rather there are other factors, perhaps their relatively weak socio-economic positions, which made them less involved. We carried out further analysis to test this hypothesis. The results gave a partial confirmation. For instance, with all other factors controlled for in the model, of people from Black Caribbean or Black African or Chinese ethnic origins or Muslim faith who are in service-class positions or who have degree qualifications, there is no statistical difference to their White peers; yet Indians with degree level qualifications were found significantly less likely than the White counterparts to be active participants $(-1.368,-1.089$ and -0.996 in the three contrasts respectively).

In sum, the patterns show that socio-demographic factors, particularly class and education, are of paramount importance in the generation of different forms of political participation. Age, sex, marital status and religious affiliation are also of considerable importance, but ethnic differences have relatively little effect. While such patterns demonstrate the continued explanatory power of social stratification, as mainstream class analysts would expect, they present an empirical challenge to poststructuralists who have long proclaimed the death of class replaced by divisions based on lifestyle or cultural identity. ${ }^{54}$

Having discussed at some lengths the relative impacts of socio-demographic factors on the generation of forms of political participation, we now turn to the impacts of socio-demographic factors and forms of political participation upon the two domains of political beliefs/actions as shown in Figure 1. We first analyse the domain of beliefs with the subsets of political trust and efficacy, and then come to that of actions with the subsets of political contact and voice. As earlier noted, we shall explore the associations at a descriptive level in the first instance before proceeding to the statistical modelling.

\footnotetext{
53 Using the most recent British Household Panel Survey of 2004, we find 47 per cent of trade-union members are drawn from the service class and only 27 per cent from the working class. For further discussion in this regard, see M. Savage, Y. Li and G. Tampubolon, 'Rethinking the Politics of Social Capital: Challenging Tocquevillian Perspectives', in R. Edwards, J. Franklin and J. Holland, eds, Social Capital: Concepts, Policy and Practice (London: Sage, 2006), pp. 70-94; Hall, 'Social Capital in Britain'; Li, Savage and Pickles, 'Social Capital and Social Exclusion'; and Y. Li and A. Pollert, The Unorganized Worker in WERS 2004: Socio-demographic Attributes, Workplace Characteristics and Work-life Experience (London: DTI and RSS, 2006).

${ }^{54}$ Pakulski and Waters, The Death of Class; A. Elliott and C. Lemert, The New Individualism (London: Routledge, 2006); and D. Denney, Risk and Society (London: Sage, 2005).
} 
TABLE 3 Percentage of Respondents with Positive Answers to Political Trust/Efficacy

\begin{tabular}{lccccc}
\hline \hline & $\begin{array}{c}\text { Political } \\
\text { Activist }\end{array}$ & $\begin{array}{c}\text { Expert } \\
\text { Citizen }\end{array}$ & $\begin{array}{c}\text { Everyday } \\
\text { Maker }\end{array}$ & $\begin{array}{c}\text { Non- } \\
\text { Participant }\end{array}$ & All \\
\hline Trust & & & & & \\
$\quad$ Police & 78.8 & 84.4 & 81.6 & 77.3 & 80.1 \\
$\quad$ Courts & 73.4 & 74.7 & 74.6 & 68.8 & 72.3 \\
$\quad \begin{array}{l}\text { Local government } \\
\text { Parliament }\end{array}$ & 50.6 & 52.8 & 51.9 & 49.3 & 51.0 \\
$\quad$ Politicians & 37.7 & 38.2 & 35.8 & 33.3 & 35.4 \\
Efficacy & 24.3 & 23.4 & 21.9 & 23.0 & 22.8 \\
$\quad$ At the local level & 56.9 & 53.1 & 44.8 & 34.9 & 43.4 \\
$\quad$ At the national level & 33.9 & 26.5 & 24.7 & 20.2 & 24.0 \\
\hline \hline
\end{tabular}

Here, Bang's analysis would lead us to expect that, as compared with Everyday Makers and with Non-Participants in particular, Expert Citizens would have a greater level of trust in the political institutions, albeit not necessarily in the incumbents of those institutions, and would feel more efficacious at both local and national levels. As previously noted, there are five component questions in relation to political trust, and two in relation to efficacy, each with four categories. For trust, the categories are: (1) a lot; (2) a fair amount; (3) not very much; and (4) not at all. For efficacy, the categories are: (1) definitely agree; (2) tend to agree; (3) tend to disagree; and (4) definitely disagree. For ease of presentation, we combined the first two categories as the positive response to trust or efficacy in cross-tabulations (Table 3) but retained the four categories in constructing the latent variable scores for modelling (Table 4).

The data on trust in Table 3 show that people in Britain have a remarkable understanding of different kinds of political trust. Most people have a very high level of trust in political institutions such as the police or courts (80 and 72 per cent respectively) and a rather low level of trust in politicians (23 per cent). The gradient is very clear, echoing existing research on trust in the United States. ${ }^{55}$ With regard to differences amongst the four groups of participants, we find that the major line of division was between the three activist groups of participants on the one hand, and the Non-Participants on the other. This being the case, it is also the case that Expert Citizens exhibit greater trust than Everyday Makers.

Turning to political efficacy, ${ }^{56}$ we find that people tend to believe that they can influence decisions affecting local rather than national levels. In this regard, Bang's distinction between the local and global levels seems imprecise. Bang's expectation that Expert Citizens would feel more efficacious at both national and local levels than Everyday

55 Paxton, 'Is Social Capital Declining in the United States?' It is noted here that trust in parliament is low. This is probably due to the imprecise wording in the questionnaire on parliament, failing to differentiate parliament as a political institution or as the behaviour of the politicians there. It could also be due to the fact that the two items (Politicians, Parliament) were asked one after another so that the respondents might have quickly associated parliament with people running the parliament whose behaviour as covered in the media frequently fell short of people's expectations of them.

56 We use the term 'efficacy' in the sense of Campbell et al. as 'the feeling that individual political action does have, or can have, an impact upon the political process ... It is the feeling that political and social change is possible and that the individual citizen can play a part in bringing about this change.' Cited in Fahmy, 'Ethnicity, Citizenship and Political Participation', p. 9. 
Makers has empirical support, but his notion that the latter would act locally, but think globally, is ill-defined and hence hard to substantiate. The much higher levels of efficacy at the local than the national level suggest, unsurprisingly, that people feel that decision making in Whitehall is remote, little influenced by their own efforts. ${ }^{57}$

Having explored the basic association between forms of political participation and trust/efficacy, we now proceed to statistical modelling (see Table 4). As earlier noted, the latent scores were standardized so that we can more easily compare the effects of various explanatory variables. ${ }^{58}$ Three models were constructed for each subset. In Model 1, only the four groups of political participants were included as the explanatory variable; in Model 2, demographic and ethno-religious variables were added; and, finally, in Model 3 class and education were added. As the inclusion of more explanatory variables tends to weaken the effects of previously included variables, we would expect a weaker association between the respondent's form of political participation and our outcome variables (trust and efficacy) as we proceed from simpler to more complicated models. The key question is: to what extent does the inclusion of new variables reduce the effects of forms of political participation ? $^{59}$

In Table 4 we can see that, in terms of trust, Political Activists and Expert Citizens tend to have similar scores, which are nevertheless markedly and significantly ${ }^{60}$ higher than those of Everyday Makers who, in turn, are significantly more trusting than NonParticipants, even when demographic and ethnic-religious (Model 2) and class and

57 As the responses to the two efficacy questions were multiple-coded, it is possible to explore the relationship in different ways. We present, in Table 1 of Appendix 1, two sets of such analysis (all appendix tables are available at $<$ http://www.ccsr.ac.uk/staff/yaojun.htm $>$ ). In the first set, we report findings on logit regression models for efficacy at the local and the national levels respectively. In the second set, we use multinomial logit analysis with LocN NatN (efficacious at neither local nor national level) as the reference category based on the four-way variable constructed from the two binary-response arrangement as below:

\begin{tabular}{|l|l|l|}
\hline & National Yes & National No \\
\hline Local yes & LocY NatY & LocY NatN \\
\hline Local no & LocN NatY & LocN NatN \\
\hline
\end{tabular}

As shown in Appendix Table 1, controlling for all other socio-demographic factors, we find, under the heading of 'Local' for efficacy at the local level, a very clear gradient for the three activist groups $(0.584,0.432$ and 0.226 for Political Activists, Expert Citizens and Everyday Makers respectively, all highly significant). Yet, with regard to efficacy at the national level, we do not find significantly higher values for Expert Citizens. One might ponder why this is the case. One reason is that this kind of analysis overlooks the multiple-reply nature of the responses. Looking at the data in the multinomial logit part, we find clear gradients for the three groups with regard to efficacy at both local and national levels, and at the local and yet not at the national levels, but no difference at national but not local levels. Thus, the patterns in the multinomial logit analysis better capture the nature of the relationship between the participant groups.

${ }^{58}$ See Table 2 in Appendix 1 for factor loadings on trust and efficacy, and mean standardized scores by the participant groups. The correlation between the two scores is 0.42 , significant at the 0.001 level.

59 At the bottom of Table 4, we present information on the improvement of fit of Model 2 over Model 1, and of Model 3 over Model 2. As would be expected, the additional blocks of variables were all statistically significant.

${ }^{60}$ Further analysis shows that, as compared with Everyday Makers, Expert Citizens tend to be significantly more trusting and efficacious ( $p=0.011,0.003$ and 0.096 for trust, and $0.000,0.000$ and 0.000 for efficacy). Although the difference between the two groups in Model 3 for trust is only marginally significant on the conventional criterion, we would argue that it is substantively important, as the model controls for many socio-demographic factors. We thank the Editor and one of our Reviewers for alerting us to the need of conducting analysis on this crucial point. 
TABLE 4 Regression Coefficients on Standardized Scores of Political Trust and Efficacy

\begin{tabular}{|c|c|c|c|c|c|c|}
\hline & \multicolumn{3}{|c|}{ Trust } & \multicolumn{3}{|c|}{ Efficacy } \\
\hline & Model 1 & Model 2 & Model 3 & Model 1 & Model 2 & Model 3 \\
\hline \multicolumn{7}{|l|}{ Political capital } \\
\hline Political Activist & $0.192 * * *$ & $0.230 * * *$ & $0.141 * * *$ & $0.492 * * *$ & $0.475 * * *$ & $0.363 * * *$ \\
\hline Expert Citizen & $0.220 * * *$ & $0.242 * * *$ & $0.143 * * *$ & $0.336 * * *$ & $0.331 * * *$ & $0.211 * * *$ \\
\hline Everyday Maker & $0.135 * * *$ & $0.144 * * *$ & $0.089 * * *$ & $0.210 * * *$ & $0.205 * * *$ & $0.136 * * *$ \\
\hline Non-Participant (ref.) & & & & & & \\
\hline \multicolumn{7}{|l|}{ Age } \\
\hline $16-24$ & & 0.013 & $-0.106 *$ & & -0.027 & $-0.140 * *$ \\
\hline $25-39$ & & -0.045 & $-0.123 * * *$ & & $0.107 * * *$ & -0.006 \\
\hline $40-59$ & & $-0.075^{* *}$ & $-0.123 * * *$ & & $0.088 * *$ & 0.019 \\
\hline $60+$ (ref.) & & & & & & \\
\hline \multicolumn{7}{|l|}{ Sex } \\
\hline Female & & 0.027 & $0.049 *$ & & 0.020 & $0.049 *$ \\
\hline Male (ref.) & & & & & & \\
\hline \multicolumn{7}{|l|}{ Marital status } \\
\hline Never married & & 0.059 & 0.044 & & 0.033 & 0.024 \\
\hline Once married & & -0.011 & 0.016 & & $-0.071^{* *}$ & -0.034 \\
\hline Married (ref.) & & & & & & \\
\hline \multicolumn{7}{|l|}{ Ethnicity } \\
\hline White (ref.) & & & & & & \\
\hline Black Caribbean & & $-0.193 * * *$ & $-0.186 * * *$ & & $0.203 * * *$ & $0.216 * * *$ \\
\hline Black African & & $0.299 * * *$ & $0.255^{* * *}$ & & $0.230 * * *$ & $0.193 * * *$ \\
\hline Indian & & $0.192 *$ & $0.175^{*}$ & & 0.045 & 0.028 \\
\hline Pakistani & & $0.207 *$ & $0.216^{*}$ & & 0.105 & 0.120 \\
\hline Bangladeshi & & $0.232 *$ & $0.268 * *$ & & 0.159 & $0.203 \dagger$ \\
\hline Chinese & & $0.428 * * *$ & $0.352 * *$ & & -0.005 & -0.066 \\
\hline Other & & $0.203 * * *$ & $0.178 * * *$ & & 0.056 & 0.036 \\
\hline \multirow{2}{*}{\multicolumn{7}{|c|}{ Religion }} \\
\hline Christian (ref.) & & & & & & \\
\hline Buddhist & & 0.018 & 0.014 & & $0.521 * *$ & $0.519 * *$ \\
\hline Hindu & & 0.127 & 0.109 & & 0.106 & 0.088 \\
\hline Jewish & & -0.205 & -0.256 & & 0.023 & -0.028 \\
\hline Muslim & & $0.178 *$ & $0.194 * *$ & & 0.134 & $0.169 \dagger$ \\
\hline Sikh & & 0.077 & 0.089 & & $0.178 \dagger$ & $0.198 \dagger$ \\
\hline Other & & $-0.297 * * *$ & $-0.323 * * *$ & & 0.091 & 0.066 \\
\hline None & & $-0.084 * *$ & $-0.098 * * *$ & & 0.003 & -0.014 \\
\hline \multicolumn{7}{|l|}{ Class } \\
\hline Service & & & $0.147 * * *$ & & & $0.144 * * *$ \\
\hline Intermediate & & & 0.038 & & & 0.024 \\
\hline Student & & & $0.278 * * *$ & & & $0.163 * *$ \\
\hline Working (ref.) & & & & & & \\
\hline \multicolumn{7}{|l|}{ Education } \\
\hline Degree + & & & $0.273 * * *$ & & & $0.378 * * *$ \\
\hline Diploma/A Level & & & $0.118 * * *$ & & & $0.213 * * *$ \\
\hline Trade app/O Level & & & $0.127 * * *$ & & & $0.209 * * *$ \\
\hline Primary/None (ref.) & & & & & & \\
\hline \multirow{4}{*}{$\begin{array}{l}\text { Constant } \\
R^{2} \\
\text { Model comparison, } F \\
N\end{array}$} & $-0.165 * * *$ & $-0.154 * * *$ & $-0.254 * * *$ & $-0.218 * * *$ & $-0.291 * * *$ & $-0.422 * * *$ \\
\hline & 0.008 & 0.021 & 0.039 & 0.026 & 0.034 & 0.057 \\
\hline & & $17.40^{\mathrm{a} * * *}$ & $24.80^{\mathrm{b} * * *}$ & & $8.33^{\mathrm{a} * * *}$ & $33.82^{\mathrm{b} * * *}$ \\
\hline & 15,418 & 15,395 & 15,395 & 15,418 & 15,395 & 15,395 \\
\hline
\end{tabular}

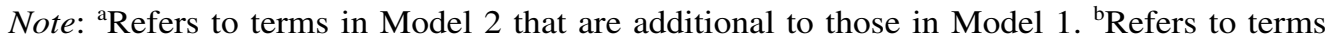
in Model 3 that are additional to those in Model 2. $\dagger p<0.10, * p<0.05, * * p<0.01$, $* * * p<0.001$. 
education (Model 3) are taken into account. The evidence here lends support to Bang's distinction between Expert Citizens and Everyday Makers. With regard to patterns associated with socio-demographic factors, one could discern a somewhat concave shape for age. Moreover, people from Black Caribbean origins, and those with 'other' or no religious affiliations tend to have lower trust. Finally, people in higher class positions and with higher educational qualifications in particular tend to have higher levels of trust, holding constant all other variables in the models.

Turning to data on efficacy in Table 4, we find, first of all, a much sharper gradient associated with different forms of political participation than was the case with trust. Political Activists have higher scores than Expert Citizens, who in turn have (significantly - see fn. 60) higher scores than Everyday Makers, who in turn have significantly higher scores than Non-Participants. Moreover, as the scores on trust and efficacy are standardized, one can clearly see that the magnitudes of coefficients on efficacy associated with each of the activist groups are higher than those on trust. In other words, different forms of political participation seem to be more closely related to efficacy than to trust. The patterns here again lend support to the heuristic value of Bang's distinction, although our development of his work resulting in a four-category variable appears more useful.

A comparison between the patterns on efficacy and those on trust as revealed by the various socio-demographic groups is also of interest here. While, for trust, age displays a clearly concave shape as noted above, a somewhat convex shape is found for efficacy. That means that, as compared with the youngest and the oldest groups, those aged 25-59, are, other things being equal, less trusting, but believe themselves to be more efficacious. ${ }^{61}$ People of Black Caribbean origins are less trusting, but have more belief in their own efficacy, than the White reference group. People of Black African origins are at once trusting and efficacious. As for the other ethnic groups, their patterns of higher levels of trust do not hold for efficacy. The effects of class are similar in the two subsets, whilst those of education are stronger as regards efficacy than trust. The notable effects of education, which are of comparable sizes to those of forms of political participation, suggest that highly educated people tend to have higher levels of information-processing, critical and analytical abilities which are essential for political participation, just as they are for civic engagement. $^{62}$

Finally in this section, we turn to the relationship between forms of political participation and political contact and voice. As indicated in Figure 1, we hypothesized that political participation would engender greater trust and efficacy, ${ }^{63}$ which in turn would impact on

${ }^{61}$ This confirms the results of Pattie, Seyd and Whiteley, Citizenship in Britain, Table 2.18, p. 67. Yet, further analysis shows that it is not the youth per se but socio-economic position that is making the difference. Those in the youngest group, who are in the service class or who have university qualifications or who are actively engaged as Political Activists or Expert Citizens, have no less belief in efficacy than their reference groups.

${ }^{62}$ Whether education generates the 'Culture of Critical Discourse' or the information-processing capacities is difficult to establish. See A. Gouldner, The Future of the Intellectuals and the Rise of the New Class (London: Macmillan, 1979), and Chan and Goldthorpe, 'The Social Stratification of Theatre, Dance and Cinema Attendance', for respective arguments. Whatever the mechanisms, it seems reasonable to suggest, as Li, Savage and Pickles ('Social Capital and Social Exclusion') argue in the case of civic engagement, that economic (class) and cultural (education) resources are both important factors for effective political participation.

${ }^{63}$ Of course, we accept that it is difficult to establish the causal order without panel data. Using the British Household Panel Survey, Li, Pickles and Savage, 'Social Capital and Social Trust', Table 4, show that informal social capital at Wave 7 had a positive effect upon generalized trust in Wave 10, even when prior levels of trust (measured at Wave 8) were taken into account. While their analysis does not exclude the possibility that people with prior trust were more likely to have higher levels of informal social capital in the first place, it does show that informal social capital helps generate trust. 
TABLE 5 Participation in Civic Activities in the Last Twelve Months (Percentage Giving Positive Answers)

\begin{tabular}{|c|c|c|c|c|c|}
\hline & $\begin{array}{l}\text { Political } \\
\text { Activist }\end{array}$ & $\begin{array}{l}\text { Expert } \\
\text { Citizen }\end{array}$ & $\begin{array}{l}\text { Everyday } \\
\text { Maker }\end{array}$ & $\begin{array}{l}\text { Non- } \\
\text { Participant }\end{array}$ & All \\
\hline \multicolumn{6}{|l|}{ Contacted a public official working } \\
\hline $\begin{array}{l}\text { for your local council } \\
\text { Contacted a local councilor }\end{array}$ & $\begin{array}{l}28.1 \\
20.2\end{array}$ & $\begin{array}{l}22.0 \\
13.7\end{array}$ & $\begin{array}{r}14.8 \\
9.1\end{array}$ & $\begin{array}{l}9.5 \\
5.3\end{array}$ & $\begin{array}{c}14.8 \\
9.2\end{array}$ \\
\hline Contacted a Member of Parliament & 14.4 & 8.7 & 5.1 & 2.0 & 5.2 \\
\hline $\begin{array}{l}\text { Contacted a public official working } \\
\text { for part of central government }\end{array}$ & 8.7 & 5.0 & 2.4 & 1.0 & 2.8 \\
\hline Signed a petition & 40.0 & 29.6 & 26.2 & 12.6 & 22.5 \\
\hline Attended a public meeting or rally & 20.8 & 12.7 & 6.7 & 2.1 & 7.0 \\
\hline $\begin{array}{l}\text { Taken part in a public demonstration } \\
\text { or protest }\end{array}$ & 6.6 & 2.3 & 1.2 & 0.6 & 1.6 \\
\hline
\end{tabular}

political contact and voice. The basic patterns are shown in Table 5 where we find that 15 per cent of the respondents had contacted a public official working for the local council, 10 per cent had contacted a local councillor, 23 per cent had signed a petition, etc. Comparing the responses by the different participant groups, we see a very clear pattern, namely, that Political Activists are most active, followed by Expert Citizens, and then Everyday Makers. The Non-Participants are much less likely to have made such contacts or exercised such voices.

The data in Table 6 are regression coefficients on standardized scores on contact and voice. ${ }^{64}$ In each part, we again have three models. What is different from Table 4 is that here we include in Model 2 all the socio-demographic variables and, as explained earlier, in Model 3 we add standardized scores on trust and efficacy.

The patterns shown in Table 6 are very clear. The coefficients on the three activist groups are significant in all three models, for contact and voice alike. ${ }^{65}$ The gradients are evident, too. The magnitudes run in the rough order of 3: 2: 1 for Political Activist, Expert Citizens and Everyday Makers; and the sizes of the effects are not much reduced when we move from Model 1 to Model 3. This shows that the participation variable we have constructed, significantly based on Bang's theoretical expectations, gives a fairly good representation of the differences in the population with regard to making political contact and exercising political voice.

With regard to the effects of socio-demographic variables, we find, as shown in Models 2 and 3, that making contacts and exercising voices are mainly a white, middle-aged, middle-class and male sphere of activity. Thus, the younger groups, women, non-married and people of minority ethnic origins are significantly less likely to have contacted public officials or voiced their disaffections in various forms of protest in the interest of public

\footnotetext{
${ }^{64}$ See Table 3 in Appendix 1 for factor loadings on contact and voice, and mean standardized scores by the participant groups.

${ }^{65}$ Further analysis shows that Expert Citizens have significantly higher scores in both contact and voice than Everyday Makers in each of the models $(p=0.000)$.
} 
TABLE 6 Regression Coefficients on Standardized Scores of Contact and Voice

\begin{tabular}{|c|c|c|c|c|c|c|}
\hline & \multicolumn{3}{|c|}{ Contact } & \multicolumn{3}{|c|}{ Voice } \\
\hline & Model 1 & Model 2 & Model 3 & Model 1 & Model 2 & Model 3 \\
\hline \multicolumn{7}{|l|}{ Political capital } \\
\hline Political Activist & $1.025 * * *$ & $0.853 * * *$ & $0.820 * * *$ & $1.088 * * *$ & $0.923 * * *$ & $0.886 * * *$ \\
\hline Expert Citizen & $0.614 * * *$ & $0.465 * * *$ & $0.450 * * *$ & $0.645^{* * *}$ & $0.498 * * *$ & $0.482 * * *$ \\
\hline $\begin{array}{l}\text { Everyday Maker } \\
\text { Non-Particinant (ref }\end{array}$ & $0.331 * * *$ & $0.273 * * *$ & $0.264 * * *$ & $0.372 * * *$ & $0.307 * * *$ & $0.296 * * *$ \\
\hline \multicolumn{7}{|l|}{ Age } \\
\hline $16-24$ & & $-0.327 * * *$ & $-0.318^{* * *}$ & & $-0.231 * * *$ & $-0.220 * * *$ \\
\hline $25-39$ & & $-0.199 * * *$ & $-0.208 * * *$ & & $-0.146^{* * *}$ & $k-0.155^{* * *}$ \\
\hline $40-59$ & & -0.039 & -0.052 & & -0.008 & -0.021 \\
\hline \multicolumn{7}{|l|}{$60+($ ref.) } \\
\hline \multicolumn{7}{|l|}{ Sex } \\
\hline $\begin{array}{l}\text { Female } \\
\text { Male (ref.) }\end{array}$ & & $-0.079 * * *$ & $-0.081 * * *$ & & $-0.041 \dagger$ & $-0.043 \dagger$ \\
\hline \multicolumn{7}{|l|}{ Marital status } \\
\hline Never married & & $-0.087 *$ & $-0.087 *$ & & $-0.082 *$ & $-0.082 *$ \\
\hline Once married & & $-0.072 *$ & $-0.066^{*}$ & & $-0.070^{*}$ & $-0.064 *$ \\
\hline Married (ref.) & & & & & & \\
\hline \multicolumn{7}{|l|}{ Ethnicity } \\
\hline White (ref.) & & & & & & \\
\hline Black Caribbean & & $-0.089 *$ & $-0.129 *$ & & $-0.096^{*}$ & $-0.140 * * *$ \\
\hline Black African & & $-0.137 * *$ & $-0.140 * *$ & & $-0.183 * * *$ & $k-0.188 * * *$ \\
\hline Indian & & $-0.154 \dagger$ & $-0.144 \dagger$ & & $-0.149 \dagger$ & $-0.139 \dagger$ \\
\hline Pakistani & & $-0.136^{*}$ & -0.133 & & -0.115 & -0.111 \\
\hline Bangladeshi & & 0.049 & 0.049 & & -0.010 & -0.013 \\
\hline Chinese & & $-0.353 * * *$ & $-0.316^{* * *}$ & & $-0.384 * * *$ & $*-0.344 * * *$ \\
\hline Other & & $-0.137 *$ & $-0.126^{*}$ & & $-0.171 * *$ & $-0.159 * *$ \\
\hline \multicolumn{7}{|l|}{ Religion } \\
\hline \multicolumn{7}{|l|}{ Christian (ref.) } \\
\hline Buddhist & & 0.239 & 0.177 & & 0.327 & 0.258 \\
\hline Hindu & & -0.093 & -0.094 & & -0.129 & -0.131 \\
\hline Jewish & & $0.391 \dagger$ & $0.373 \dagger$ & & $0.371 \dagger$ & $0.352 \dagger$ \\
\hline Muslim & & 0.157 & 0.155 & & 0.111 & 0.106 \\
\hline Sikh & & 0.104 & 0.087 & & 0.069 & 0.050 \\
\hline Other & & $0.168 *$ & $0.132 *$ & & $0.205^{*}$ & $0.168 *$ \\
\hline None & & 0.049 & 0.042 & & 0.046 & 0.041 \\
\hline \multicolumn{7}{|l|}{ Class } \\
\hline Service & & $0.084 *$ & $0.079 *$ & & $0.081 *$ & $0.074 *$ \\
\hline Intermediate & & 0.022 & 0.022 & & 0.012 & 0.012 \\
\hline Student & & 0.032 & -0.029 & & 0.005 & 0.017 \\
\hline Working (ref.) & & & & & & \\
\hline \multicolumn{7}{|l|}{ Education } \\
\hline Degree + & & $0.396 * * *$ & $0.372 * * *$ & & $0.394 * * *$ & $0.368 * * *$ \\
\hline Diploma/A Level & & $0.260 * * *$ & $0.244 * * *$ & & $0.258 * * *$ & $0.239 * * *$ \\
\hline $\begin{array}{l}\text { Trade app/O Level } \\
\text { Primary/None (ref.) }\end{array}$ & & $0.110 * * *$ & $0.095 * * *$ & & $0.121 * * *$ & $0.103 * * *$ \\
\hline Trust & & & $0005 * * *$ & & Primary/None (ref.) & $0000 * * *$ \\
\hline Efficacy & & & 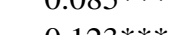 & & & -0.000 . \\
\hline Efficacy & & & $0.123^{* * *}$ & & & $0.134 * * *$ \\
\hline Constant & $-0.233 * * *$ & $-0.188 * * *$ & $-0.157 * *$ & $-0.243 * * *$ & $-0.256^{* * *}$ & $-0.222 * *$ \\
\hline$R^{2}$ & 0.086 & 0.124 & 0.134 & 0.096 & 0.126 & 0.138 \\
\hline Model comparison, $F$ & & $14.19^{\mathrm{a} * * *}$ & $40.66^{\mathrm{b} * * *}$ & & $11.14^{\mathrm{a} * * *}$ & $48.29^{\mathrm{b} * * *}$ \\
\hline$N$ & 15,454 & 15,430 & 15,395 & 15,454 & 15,430 & 15,395 \\
\hline
\end{tabular}

Note: See footnotes to Table 4. 
affairs. ${ }^{66}$ Education is a highly important factor. Another notable feature, as shown in Model 3 for both subsets, is that trust is negatively, and efficacy is positively, associated with contact and voice. This suggests that people contacted public officials or staged protests because they did not believe that the incumbents in those institutions would automatically put people's interests before their own and because they at the same time believed that they could through their own actions make a difference in the interests of public affairs. ${ }^{67}$ In addition, with this in mind, we find, surprisingly, that, even with all other socio-demographic and ethno-religious factors in the models controlled for, our participation variable has the most pronounced effects, in terms at least of the magnitudes of the coefficients, and that for both contact and voice alike.

\section{CONCLUSION}

This article is a contribution to the literature on political participation and democratic governance. Conceptually, we have built upon and developed Bang's theory on new forms of political participation, which, in our view, represents the most interesting development in the recent literature. However, following distinctions which are more implicit in Bang, we utilized two other categories, Political Activists and Non-Participants. We used the 2001 HOCS data which, at the time the analysis was commenced in October 2004, was the best, and most authoritative, dataset available for our analysis. Technically, we used the item response theory models to conduct the latent factor analysis of categorical indicator variables: the first time the model has been used in British political sociology research. From both a conceptual and a technical perspective, we believe that our research marks an important step forward in the study of political participation.

Our results are clear:

- To the extent that our data are adequate to test Bang's arguments about new forms of participation, and we return to that issue below, we can identify both Expert Citizens (14.5 per cent of our respondents) and Everyday Makers (37.3 per cent), with 8.4 per cent being Political Activists and 39 per cent Non-Participants. Unlike Bang, we then explored the socio-demographic characteristics associated with the different forms of participation. There are some clear demographic differences between our participant groups. Political Activists (people engaged in party politics and trade unions) and Expert Citizens (leaders or representatives in formal volunteering groups) are more likely to be male, middle-aged, highly-educated and in service-class jobs, whereas Everyday Makers tend to be younger, female and non-married. Non-Participants are likely to be found amongst the elderly, divorced, separated, widowed, those of minority ethnicity, Muslims, Sikhs, those in working-class positions or the poorly educated. At the same time, there is a clear relationship between the form of participation an individual follows and her feelings of political trust and efficacy and, in turn, her likelihood of making

\footnotetext{
${ }^{66}$ Further analysis for interaction effects, with all other variables in the models still controlled for, shows that the younger age groups who were in the service class or who had degree qualifications were no less likely to have made contact or exercised voice than their older counterparts and that minority ethnic groups who were in the service class or in the Political Activist group were more likely to have contacted public officials but less likely to have exercised voices in the interest of public affairs.

67 At a bivariate level, there is no significant association between trust and contact $(r=0.006, p=0.443)$, or between trust and voice $(r=0.009, p=0.238)$, although efficacy is weakly but significantly associated with contact and voice ( $r=0.142$ and $r=0.153$ respectively, both significant at the 0.001 level).
} 
political contacts and exercising political voices. Consequently, we would argue that Bang's classification and, more importantly, our re-specification, of forms of political participation is useful at an empirical level.

- As far as explaining why individuals undertake particular forms of participation is concerned, our analysis shows that access to economic, social and cultural resources is of crucial importance. People in the service class (professionals and managers) and with higher educational qualifications are most likely to be Political Activists and Expert Citizens. The analysis here has strong resonance with recent social capital research. ${ }^{68}$ The most disadvantaged social groups, namely, those in the working class and with little formal education, are least likely to be engaged in political participation. Informal political participation, especially as Political Activists and Expert Citizens, requires social and cultural capital of which the working class have less and, when they do have some, such capital tends to be of a different type which is less valued in mainstream politics. ${ }^{69}$ The close association between economic, social and cultural capital and forms of political participation suggests that the mainstream political participation literature has so far failed to address the underlying structural causes of non-participation sufficiently.

In contrast, other demographic differences in relation to forms of participation, including ethno-religious differences, are relatively small. On the one hand, we did find that Black Caribbeans, Muslims and Sikhs were significantly less likely to be Political Activists, Expert Citizens or Everyday Makers, but the effect was much reduced when we controlled for education and, especially, class. People of Jewish origins were, on the other hand, much more likely to be Expert Citizens. To put it another way, to increase participation as valued in mainstream politics (a debatable point), it is crucially important that ethnically disadvantaged people gain access to cultural capital, increase their social mobility and grow their economic capital.

-Our results suggest that the forms of political participation we have identified, based on a critical assessment of Bang, are useful for explaining levels of political trust and efficacy and, through them, levels of political contact and voice. Even controlling for class and education, as well as the other ethno-religious and demographic factors, the variable on forms of political participation remains highly significant.

In sum, our research shows that social stratification cuts deep into the realm of political participation generation and that the form of political participation the citizens adopt also plays an important and independent role in shaping political beliefs and actions.

We cannot finish without returning to the question of the adequacy of our data to test Bang's analysis. As we made clear at the outset, we recognize that the absence of data about how our respondents feel about their political participation such as 'doing it with confidence' or 'for joy' means that it is difficult to identify Everyday Makers in a way which does full justice to his model. To test Bang more thoroughly, one would need data specifically designed for that purpose. While no such quantitative data are in existence,

${ }^{68}$ Putnam, Bowling Alone; Hall, 'Social Capital in Britain'; Li, Savage and Pickles, 'Social Capital and Social Exclusion'; and Li, Pickles and Savage, 'Social Capital and Social Trust'.

${ }^{69} \mathrm{Li}$, Pickles and Savage, 'Social Capital and Social Trust', find that the working class have higher levels of neighbourhood attachment than do the service class, one of the types of social capital (the other two being civic engagement and social support). Neighbourhood attachment may be regarded as a form of bonding capital which is less valued in mainstream discussions on social capital or political participation than, say, formal civic engagement. We owe this insight to one of the reviewers of a previous version of this article. 
our claim here is that we have used the best data available and that our work has conceptual cogency and empirical support. It is particularly important to emphasize that our classification of forms of participation/types of participant has empirical purchase in a way Bang would expect, namely, that Expert Citizens feel less efficacious than Political Activists, but are significantly more trusting and efficacious than Everyday Makers; and that they use contact and voice more than Everyday Makers. So, we would argue that Bang's work and our development of it deserve further attention. 